\title{
The $\mathrm{EP}_{2}$ receptor is the predominant prostanoid receptor in the human ciliary muscle
}

\author{
Toshihiko Matsuo, Max S Cynader
}

\begin{abstract}
Prostaglandins can reduce intraocular pressure by increasing uveoscleral outflow. We have previously demonstrated that the human ciliary muscle was a zone of concentration for binding sites (receptors) for prostaglandin $\mathbf{F}_{\mathbf{2} \alpha}$ and for prostaglandin $E_{2}$. Here, we try to elucidate the types of prostanoid receptors in the ciliary muscle using competitive ligand binding studies in human eye sections and computer assisted autoradiographic densitometry. Saturation binding curves showed that the human ciliary muscle had a large number of binding sites with a high affinity for prostaglandin $\mathbf{E}_{2}$ compared with prostaglandin $\mathbf{D}_{2}$ and $F_{2 \alpha}$. The binding of tritiated prostaglandin $E_{2}$ and $F_{2 \alpha}$ in the ciliary muscle was displaced most effectively by prostaglandin $E_{2}$ and 11 deoxy prostaglandin $\mathbf{E}_{1}$ (a selective $\mathbf{E P}_{2}$ prostanoid receptor agonist), whereas the binding of prostaglandin $D_{2}$ was displaced most effectively by prostaglandin $E_{2}$ and $D_{2}$. These results indicate that the dominant prostanoid receptor in the human ciliary muscle is the $\mathbf{E P}_{2}$ subclass and that there is also a small number of DP receptors.

(Brf Ophthalmol 1993; 77: 110-114)
\end{abstract}

Prostaglandins are known to reduce intraocular pressure in various species including rabbits, cats, monkeys, and humans, when given topically at low doses. The ability of prostaglandin $F_{2 \alpha}$ to lower intraocular pressure has been well documented in normal subjects ${ }^{1-3}$ and also in patients with glaucoma. ${ }^{45}$ The reduction of intraocular pressure following prostaglandin $\mathrm{E}_{2}$ administration has been observed in cats and monkeys, ${ }^{6-8}$ and the pressure lowering effect of prostaglandin $\mathrm{D}_{2}$ has also been examined in cats and rabbits. ${ }^{-11}$ However, their effects in humans have not been studied.

There are several lines of evidence indicating that prostaglandin $F_{2 u}$ lowers intraocular pressure by increasing uveoscleral outflow in monkeys. ${ }^{12-14}$ We have previously demonstrated, using an in vitro radioligand binding technique and autoradiography, that human ciliary muscle is a zone of concentration of binding sites (receptors) for prostaglandin $F_{2 \alpha}$ and for prostaglandin $\mathrm{E}_{2} .{ }^{15}$

A working classification of prostanoid receptors for five naturally occurring prostaglandins has been proposed based on pharmacological studies in which the agonist potencies of naturally occurring prostaglandins as well as other synthetic agonists and antagonists were compared. ${ }^{1617}$ Receptors sensitive to thromboxane $A_{2}$, prostaglandin $D_{2}, E_{2}, F_{2 \alpha}$, and $I_{2}$ have been designated as TP, DP, EP, FP, and
IP prostanoid receptors, respectively. The EP receptor can be further classified into three subtypes, called $\mathrm{EP}_{1}, \mathrm{EP}_{2}$, and $\mathrm{EP}_{3}$ receptors. ${ }^{1819}$ The framework of the receptor classification has been supported in part, by cloning and expression of cDNA for a human thromboxane $\mathrm{A}_{2}$ receptor. ${ }^{20}$

It is important to know the types of prostanoid receptors located on the human ciliary muscle in order to understand its role in uveoscleral outflow, and to design new drugs with more potency and fewer adverse effects. In this study we tried to elucidate the type(s) of prostanoid receptors located on the human ciliary muscle by combining receptor autoradiography with competitive binding studies with various ligands on human eye sections.

\section{Materials and methods}

\section{PREPARATION OF HUMAN EYE SECTIONS}

Human cadaveric eyes were obtained within 24 hours after death from the Eye Bank of British Columbia. The eyes from two different individuals were used: a 45-year-old man who died of heart failure and a 52-year-old woman who died of colon cancer. The eyes used in this study had no documented ocular diseases. They were frozen in isopentane cooled to $-80^{\circ} \mathrm{C}$ and stored at $-20^{\circ} \mathrm{C}$ until use. Sections of $20 \mu \mathrm{m}$ thickness were cut with a cryostat (Cambridge Instruments, Nussloch, Germany) and placed on glass slides coated with $1 \cdot 7 \%$ gelatin.

\section{IN VITRO LIGAND BINDING AND}

\section{AUTORADIOGRAPHY}

The sections were thawed at room temperature and preincubated in $50 \mathrm{mM}$ TRIS-hydrochloride buffer ( $\mathrm{pH} \mathrm{7.4)}$ containing $100 \mathrm{mM}$ sodium chloride, $3 \mathrm{mM}$ calcium chloride, and $5 \%$ (weight/volume) bovine serum albumin (Sigma, St Louis, MO) for 60 minutes at room temperature. The sections were then incubated in the same buffer containing a given concentration of tritiated prostaglandin $\mathrm{D}_{2}, \mathrm{E}_{2}$, or $\mathrm{F}_{2 \alpha}$ (Du Pont Canada, Mississauga, Ontario) for 90 minutes at room temperature, washed for 40 minutes in the ice-cold buffer containing $1 \%$ bovine serum albumin, and finally dried in an air stream. The sections were then apposed to tritium-sensitive films (Hyperfilm ${ }^{-3} \mathrm{H}$ : Amersham Canada, Oakville, Ontario) for 8 weeks in the dark.

SATURATION AND COMPETITION BINDING STUDIES Sections were incubated with $1,2,5,10$, or 20 $\mathrm{nM}$ concentration of tritiated prostaglandin $\mathrm{D}_{2}$, 
$\mathrm{E}_{2}$, or $\mathrm{F}_{2 \alpha}$ to obtain a saturation binding curve for each prostaglandin. Specific binding at each concentration was obtained by subtracting nonspecific binding (determined by addition of 10 $\mu \mathrm{M}$ corresponding unlabelled ligand) from total binding (determined without the unlabelled ligand). The density of binding sites in the ciliary muscle under different conditions was measured as described below.

For competitive binding, sections were

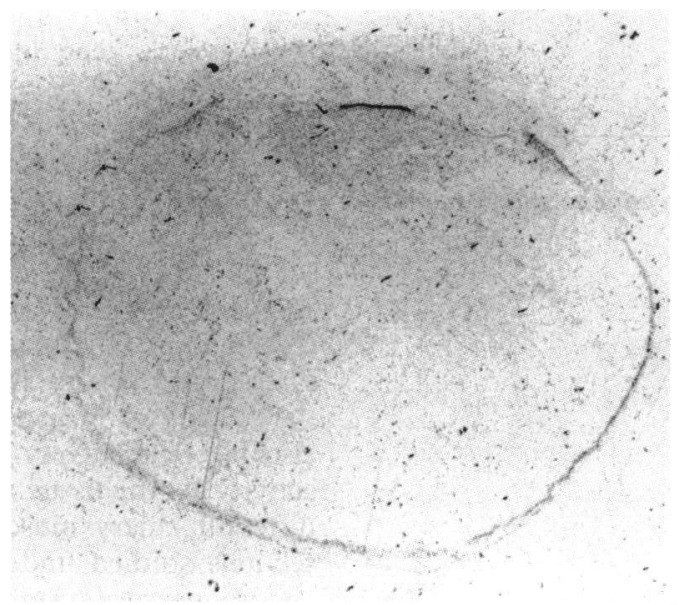

Fig $1 A$

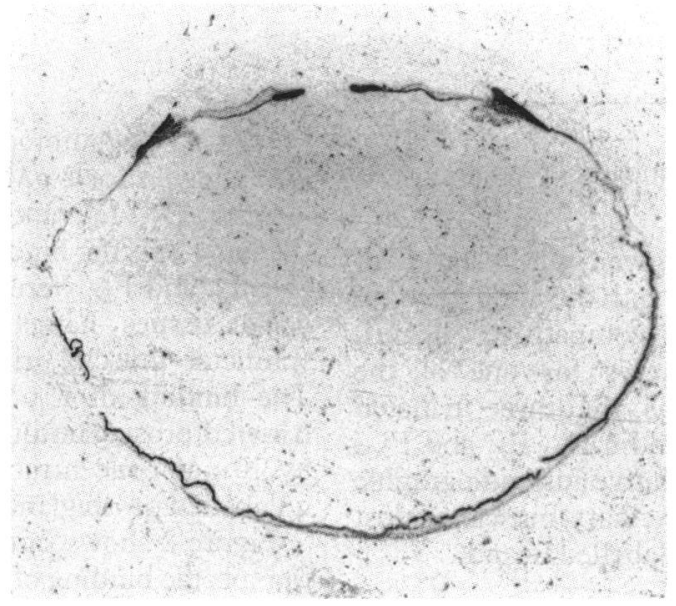

Fig $1 B$

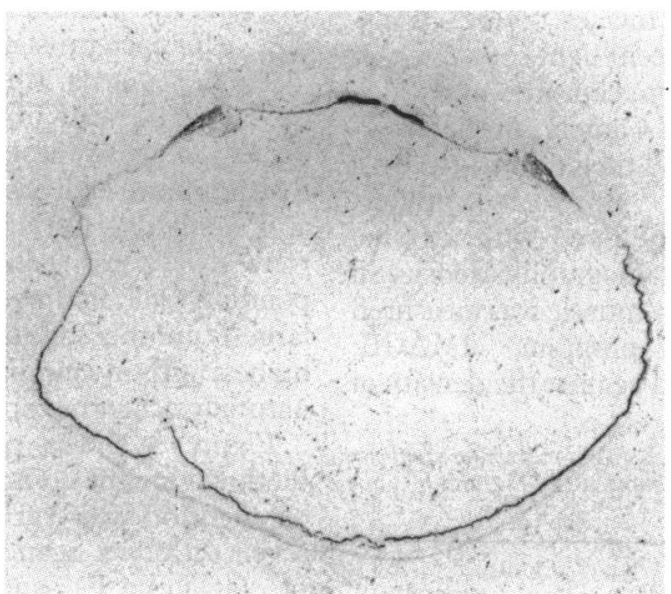

Fig $1 C$ incubated with $10 \mathrm{nM}$ of tritiated prostaglandin $\mathrm{D}_{2}, \mathrm{E}_{2}$, or $\mathrm{F}_{2 \alpha}$, together with varying concentrations $\left(10^{-9}\right.$ to $\left.10^{-3} \mathrm{M}\right)$ of seven different unlabelled ligands including prostaglandin $\mathrm{D}_{2}$, $\mathrm{E}_{2}, \mathrm{~F}_{2 \alpha}, \mathrm{U}-46619,11$-deoxy prostaglandin $\mathrm{E}_{1}, 17-$ phenyltrinor prostaglandin $\mathrm{F}_{2 \alpha}$ (all from Cayman Chemicals), or sulprostone (Schering AG, Berlin, Germany). The degree of competition for each ligand was expressed as the relative percentage between the binding of tritiated prosta-

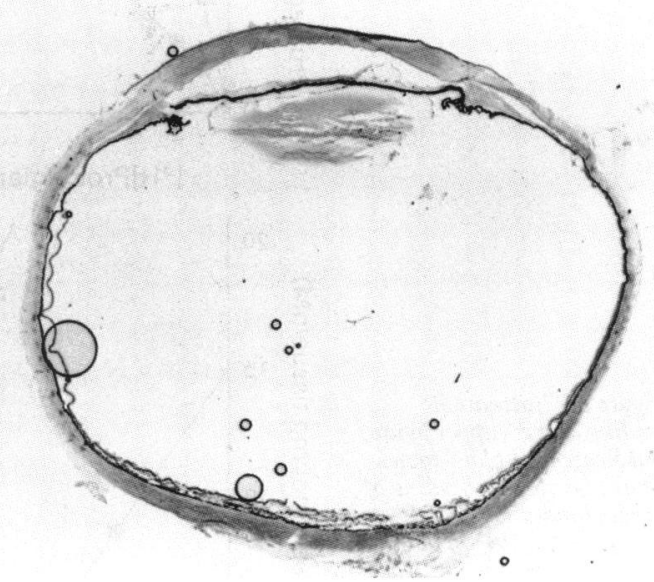

Fig $1 D$

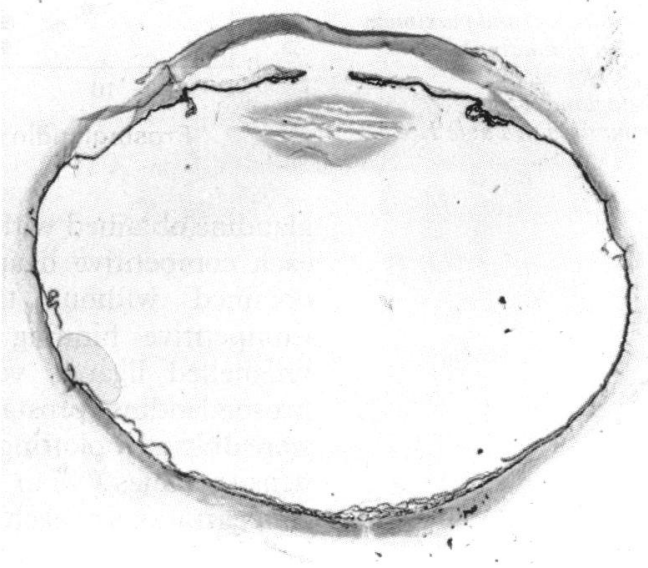

Fig 1E

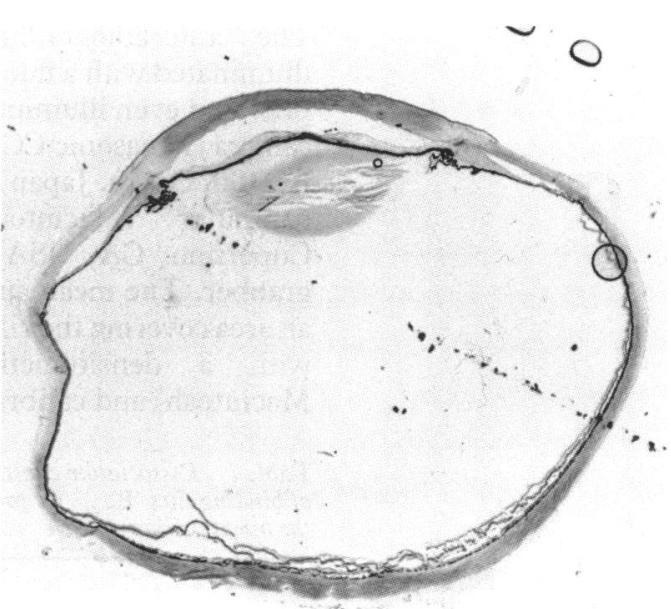

Fig $1 F$

Figure 1 Autoradiographic views of specific binding sites for $2 n M$ tritiated prostaglandin $D_{2}(A), E_{2}(B)$, and $F_{2 u}(C)$ in sections of the human eye. The binding sites for the three prostaglandins are co-localised with concentrations in the ciliary muscle, iris sphincter muscle, iris epithelium, and retina. Non-specific binding for each prostaglandin determined by addition of the corresponding $10 \mu \mathrm{M}$ unlabelled ligand is quite low. Nissl stained views of the same sections for the specific binding $(A, B$, and $C)$ are given in $D, E$, and $F$, respectively. 
Figure 2 Saturation binding curves (upper figure) and Scatchard plots (lower figure) for specific binding of prostaglandin $D_{2}(\Theta), E_{2}$ $(\mathrm{O})$, and $F_{2 \alpha}(\mathbf{\square})$ in the human ciliary muscle. Each value represents an average of four different measurements in two eye sections. The dissociation constant $\left(\mathbf{K}_{d}\right)$ and maximum number of binding sites $\left(\mathbf{B}_{\text {max }}\right.$ ) for each prostaglandin are summarised in Table 1.

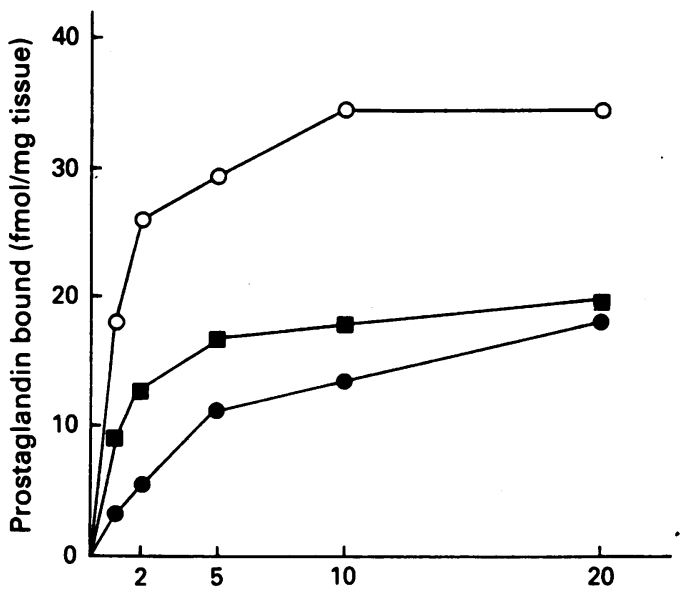

$\left[{ }^{3} \mathrm{H}\right]$ Prostaglandin concentration ( $\mathrm{nM}$ )

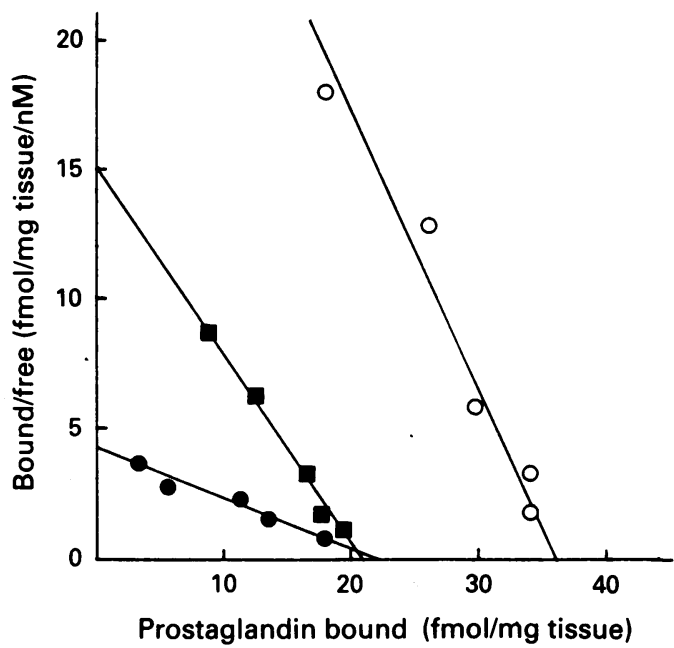

glandins obtained with a given concentration of each competitive ligand and the total binding obtained without the competitive ligand. Competitive binding curves for one of the unlabelled ligands versus the three tritiated prostaglandins (prostaglandin $\mathrm{D}_{2}, \mathrm{E}_{2}$, and $\mathrm{F}_{2 \alpha}$ ) were drawn by plotting relative autoradiographic density values (\%) in the ciliary muscle against concentrations of each unlabelled ligand.

\section{COMPUTER ASSISTED DENSITOMETRY}

The autoradiographic images were transilluminated with a fluorescent light source which provided even illumination, captured by a video camera (Panasonic CCTV Camera, Model MWBD400, Osaka, Japan) and then transmitted to a computer (Macintosh, Apple Computer, Cupertino, CA, USA) equipped with a frame grabber. The mean autoradiographic density in an area covering the ciliary muscle was measured with a densitometric program (IMAGE: Macintosh) and calibrated against the density of

Table 1 Dissociation constant $\left(\mathrm{K}_{d}\right)$ and maximum number of binding sites $\left(\mathrm{B}_{\max }\right)$ for prostaglandin $D_{2}, E_{2}$, and $F_{2 \alpha}$ in the human ciliary muscle

\begin{tabular}{lll}
\hline & $\begin{array}{l}\mathrm{K}_{d} \\
(n M)\end{array}$ & $\begin{array}{l}\mathrm{B}_{\max } \\
\text { (fmol/mg tissue) }\end{array}$ \\
\hline Prostaglandin $\mathrm{D}_{2}$ & $5 \cdot 2$ & 22 \\
Prostaglandin $\mathrm{E}_{2}$ & 0.9 & 36 \\
Prostaglandin $\mathrm{F}_{2 \mu}$ & $1 \cdot 4$ & 21
\end{tabular}

Values were obtained from Scatchard analysis of the saturation curves shown in Figure 2.

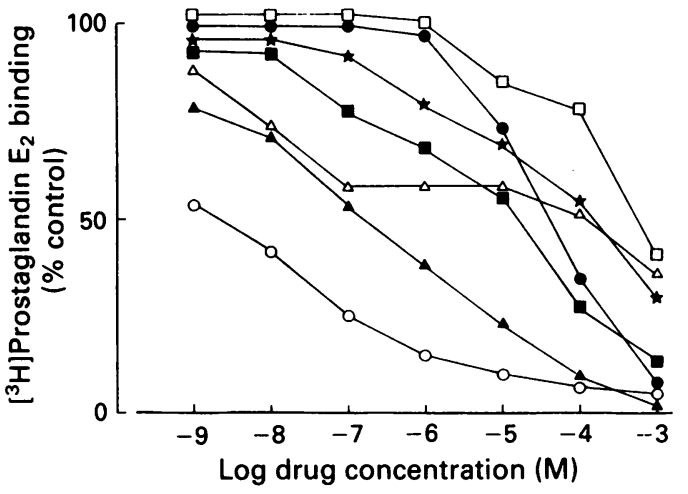

Figure 3 Binding curves for $10 \mathrm{nM}$ tritiated prostaglandin $E_{2}$ in the human ciliary muscle after competition with varying concentrations of unlabelled prostaglandin $D_{2}(O), E_{2}(O)$, $F_{2 \alpha}(\square), U-46619(\square), 11$-deoxy prostaglandin $E_{1}(\Delta)$, 17-phenyltrinor prostaglandin $F_{2 \alpha}(\star)$, and sulprostone $(\triangle)$. Each value represents an average of four different measurements.

co-exposed ${ }^{3} \mathrm{H}$-plastic standards $\left(\left[{ }^{3} \mathrm{H}\right]\right.$ Microscales, Amersham). This enabled us to compare the density of images from different films and also to convert Gray scales to values of radioactivity per mg tissue. The density values in four different ciliary muscular areas from two eye sections studied under the same experimental conditions were averaged, as any one eye section contained two areas of the ciliary muscle (see Fig 1).

\section{Results}

Figure 1 shows autoradiographic views of specific binding sites for $2 \mathrm{nM}$ concentrations of prostaglandin $D_{2}, E_{2}$, and $F_{2 \alpha}$ in the human eye sections. Specific binding sites for prostaglandin $D_{2}, E_{2}$, and $F_{2 \alpha}$ were concentrated in the same ocular tissues, namely, the ciliary muscle, iris sphincter muscle, iris epithelium, and retina. The binding of $2 \mathrm{nM}$ concentrations of each tritiated prostaglandin was displaced completely by $10 \mu M$ concentrations of the corresponding unlabelled prostaglandin.

Figure 2 shows saturation binding curves for the specific binding of prostaglandin $\mathrm{D}_{2}, \mathrm{E}_{2}$, and $F_{2 \alpha}$ in the ciliary muscle and Scatchard analysis of the saturation data. The dissociation constant $\left(K_{\mathrm{d}}\right)$ and the maximum number of binding sites $\left(B_{\max }\right)$ for each prostaglandin are summarised in Table 1. Values of $B_{\max }$ were expressed as $\mathrm{fmol} /$ $\mathrm{mg}$ tissue instead of the more usual $\mathrm{fmol} / \mathrm{mg}$ protein because these values were obtained by densitometric analysis as described in Materials and methods. Levels of non-specific binding were always less than $20 \%$ those of the corresponding total binding. Prostaglandin $\mathrm{E}_{2}$ had the largest number of binding sites and also the highest affinity binding sites among the three naturally occurring prostaglandins.

Figure 3 shows plots of prostaglandin $E_{2}$ binding in the human ciliary muscle after competition with various concentrations of the seven different ligands. Figures 4 and 5 show prostaglandin $F_{2 \alpha}$ and $D_{2}$ binding curves after competition with the same seven unlabelled ligands, respectively. The concentrations $\left(\mathrm{IC}_{50}\right)$ of each ligand required to cause $50 \%$ inhibition of the binding of $10 \mathrm{nM}$ tritiated prostaglandins are summarised in Table 2. 
Table 2 The concentration $\left(I C_{50}\right)$ of each ligand to cause $50 \%$ inhibition of the binding of $10 \mathrm{nM}$ prostaglandin $D_{2}, E_{2}$, and $F_{2 \alpha}$ in the human ciliary muscle

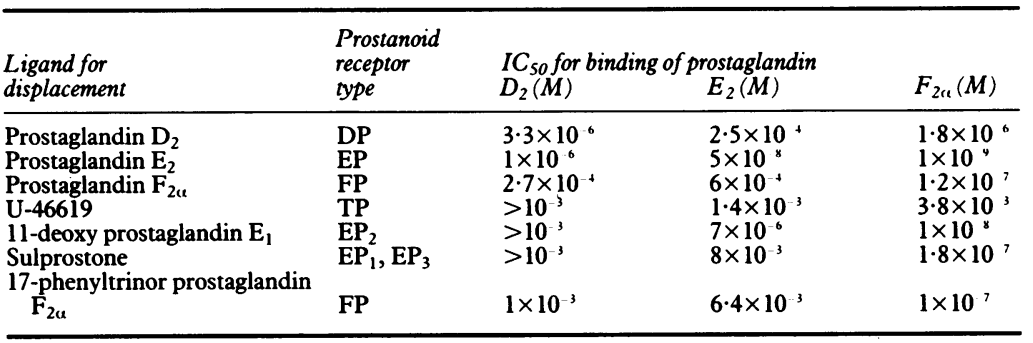

Values were obtained from curves in Figures 3, 4, and 5.

The order of potency to displace the binding of prostaglandin $E_{2}$ was: prostaglandin $E_{2}>11-$ deoxy prostaglandin $\mathrm{E}_{1}\left(\mathrm{EP}_{2}\right.$ agonist) $>$ prostaglandin $\mathrm{F}_{2 \alpha}>$ prostaglandin $\mathrm{D}_{2}>17$-phenyltrinor prostaglandin $F_{2 \alpha}$ (FP agonist)=sulprostone $\left(E_{1}, E_{3}\right.$ agonist) $>\mathrm{U}-46619$ (TP agonist). This order indicates that the binding of prostaglandin $E_{2}$ in the human ciliary muscle is predominantly to the $\mathrm{EP}_{2}$ receptor subtype.

The order of potency to displace the binding of prostaglandin $\mathrm{F}_{2 \alpha}$ was: prostaglandin $\mathrm{E}_{2}>11$ deoxy prostaglandin $\mathrm{E}_{1}\left(\mathrm{EP}_{2}\right.$ agonist $)>17$ phenyltrinor prostaglandin $\mathrm{F}_{2 \alpha}$ (FP agonist)= prostaglandin $\mathrm{F}_{2 \alpha}=$ sulprostone $\left(\mathrm{EP}_{1}, \mathrm{EP}_{3}\right.$ agonist) $>$ prostaglandin $\quad \mathrm{D}_{2}>\mathrm{U}-46619 \quad$ (TP agonist). Thus prostaglandin $E_{2}$ and 11-deoxy prostaglandin $E_{1}$ displaced the binding of prostaglandin $F_{2 \alpha}$ more effectively than did prostaglandin $\mathrm{F}_{2 \alpha}$ itself, indicating that prostaglandin $\mathrm{F}_{2 \alpha}$ binds to the $\mathrm{EP}_{2}$ receptor and that the number of FP receptors in the ciliary muscle is limited.

The order of potency to displace the binding of prostaglandin $\mathrm{D}_{2}$ was: prostaglandin $E_{2}>$ prostaglandin $D_{2} \gg$ prostaglandin $F_{2 \alpha}>17$ phenyltrinor prostaglandin $F_{2 \alpha}$ (FP agonist) $>$ sulprostone $\left(\mathrm{EP}_{1}, \mathrm{EP}_{3}\right.$ agonist $)=11$-deoxy

\section{Figure 4 Binding curves for $10 \mathrm{nM}$ tritiated prostaglandin $F_{2 \alpha}$ in the human ciliary muscle after competition with varying concentrations of unlabelled prostaglandin $\mathrm{D}_{2}(\mathrm{O}), \mathrm{E}_{2}$ (O), $F_{2 \alpha}(\square), U-46619$ (口), 11-deoxy prostaglandin $E_{1}(\Delta)$, 17-phenyltrinor prostaglandin $F_{2 \alpha}(\star)$, and sulprostone $(\triangle)$. Each value represents an average of four different}

measurements.

\section{Figure 5 Binding curves} for $10 \mathrm{nM}$ tritiated prostaglandin $\mathrm{D}_{2}$ in the human ciliary muscle after competition with varying concentrations of unlabelled prostaglandin $D_{2}(\mathrm{O}), E_{2}(\bigcirc), F_{2 \alpha}(\square)$, $U-46619$ ( $\square$, 11-deoxy prostaglandin $E_{1}(\mathbf{\Delta}), 17$ phenyltrinor prostaglandin $F_{2 \alpha}(\star)$, and sulprostone $(\triangle)$. Each value represents an average of four different measurements.
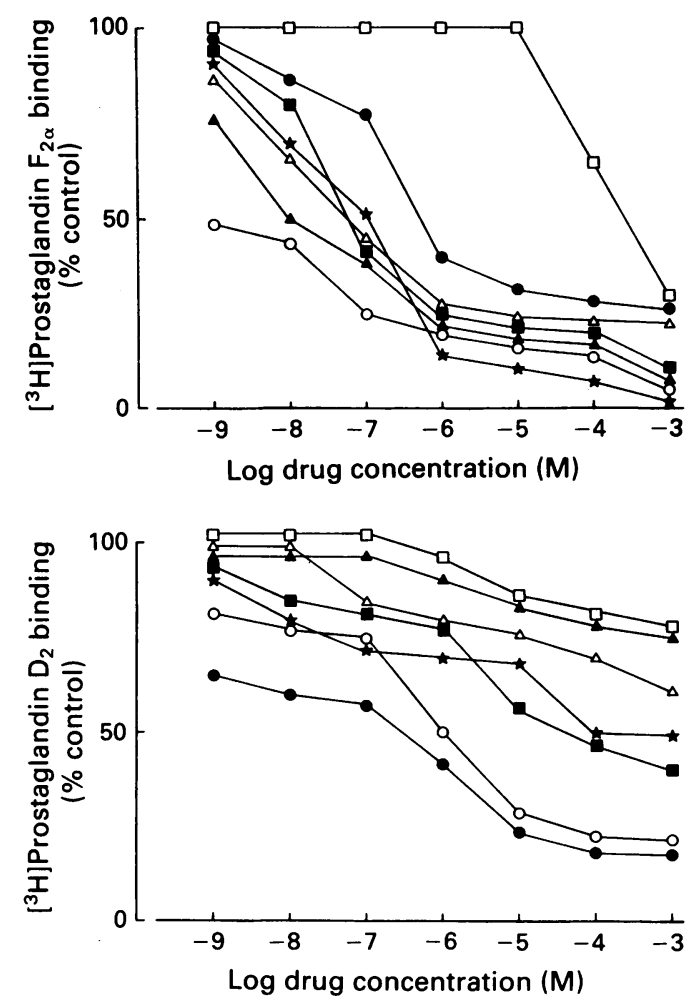

prostaglandin $E_{1}$ (EP agonist) $=\mathrm{U}-46619$ (TP agonist). The binding of prostaglandin $\mathrm{D}_{2}$ was effectively displaced by prostaglandin $\mathrm{E}_{2}$ but not by 11-deoxy prostaglandin $E_{1}$ or sulprostone, implying that prostaglandin $\mathrm{E}_{2}$ displaced prostaglandin $D_{2}$ bound to the DP receptor. This indicates that a smaller number of the DP receptor exists in the ciliary muscle in addition to the $\mathrm{EP}_{2}$ receptor found in the other two displacement studies. Interestingly, the prostaglandin $\mathrm{D}_{2}$ binding sites appear to have the same anatomical localisations as the $\mathrm{EP}_{2}$ sites, namely, the ciliary muscle, iris sphincter muscle, iris epithelium, and retina.

The results described above were reproducible in the eyes from two different individuals.

\section{Discussion}

Competitive binding studies using various selective ligands are an important approach to elucidate receptor types in a given tissue. These studies are usually done with membrane preparations obtained by homogenisation of the tissue. In this study, we have used the methods of quantitative receptor autoradiography to accomplish the same end in the ciliary body of human eye sections. This method has an advantage of requiring only very small amounts of tissue - that is, eye sections with $20 \mu \mathrm{m}$ thickness for each displacement experiment. This method is especially useful when we have to deal with rare human tissues and pathological materials such as glaucomatous eyes. In addition, this method enables us to compare displacement of binding sites in many different ocular tissues simultaneously in the same eye section.

There has been one report which describes prostaglandin $\mathbf{E}_{2}$-binding studies using membrane preparations of the isolated bovine iris ciliary body. ${ }^{21}$ The binding sites for prostaglandin $E_{2}$ detected in this report would be heterogeneous with regard to their locations and receptor types, since the isolated iris ciliary body still contains many different structures as the ciliary muscle, ciliary and iris epithelium. It is also difficult to isolate purely the human ciliary muscle from other surrounding tissues to obtain membrane preparations in an amount suitable for binding studies. In the present experiments, we performed binding studies with eye sections and measured the density of autoradiographic images on the films by computer assisted densitometry to overcome the problems mentioned above.

Prostaglandins have the ability to bind to the ocular pigments, ${ }^{22}$ which gives rise to a high level of non-specific binding and hampers pharmacological binding studies done with membrane preparations or sections from ocular tissues. We were able to reduce the binding of prostaglandins to ocular pigments by adding a high concentration (5\%) of bovine serum albumin in the incubation buffer and by washing sections for a long period (40 minutes in the present studies) as described previously. ${ }^{15}$

Saturable and displaceable binding sites for prostaglandin $\mathrm{D}_{2}, \mathrm{E}_{2}$, and $\mathrm{F}_{2 \alpha}$ were observed in the human ciliary muscle, indicating that these binding sites could be receptors for prosta- 
glandins. The $K_{\mathrm{d}}$ values for prostaglandin $\mathrm{D}_{2}$, $\mathrm{E}_{2}$, and $\mathrm{F}_{2 \alpha}$ were in the nanomolar range. These values are in good agreement with dissociation constants for prostaglandins found in membrane preparations of the bovine iris-ciliary body ${ }^{21}$ and of the rat kidney, ${ }^{23}$ or in rat brain synaptic membrane preparations, ${ }^{24}$ suggesting that binding sites in these tissues represent similar populations of prostaglandin receptors.

The $K_{\mathrm{d}}$ values for prostaglandin $\mathrm{E}_{2}(0.9 \mathrm{nM})$ and $F_{2 \alpha}(1.4 \mathrm{nM})$ were similar to each other, while the $K_{\mathrm{d}}$ value for prostaglandin $\mathrm{D}_{2}(5 \cdot 2 \mathrm{nM})$ was apparently larger than the other two values. Furthermore, competitive displacement studies demonstrated that prostaglandin $E_{2}$ and $F_{2 \alpha}$ bound to the same $\mathrm{EP}_{2}$ receptor in the ciliary muscle. These results indicate that there are at least two different types of binding sites (receptors) for prostaglandins in the human ciliary muscle. Our conclusion is that these are the $\mathrm{EP}_{2}$ and DP prostanoid receptors, based on the displacement studies as described in Results. There are more $\mathrm{EP}_{2}$ receptors than DP receptors based on thier $B_{\max }$ values. The FP receptor could be also present, though in small quantities, in the ciliary muscle, because $B_{\max }$ values for prostaglandin $E_{2}$ and $F_{2 \alpha}$ are apparently different. More definite answers to these questions will be obtained by development of new ligands which are more sensitive and specific to each prostanoid receptor and by their use in the displacement experiments.

In rabbits, the $\mathrm{EP}_{3}$ prostanoid receptor has been shown to be involved in reduction of intraocular pressure. ${ }^{2526}$ In cats, prostaglandininduced ocular hypotension was shown to be mediated by the $\mathrm{EP}_{2}$ and DP prostanoid receptors. ${ }^{27}$ There was a correlation between dose related relaxation of the isolated ciliary muscle and reduction of intraocular pressure in cats, which was obtained only with selective $\mathrm{EP}_{2}$ or DP agonists.

Our findings have indicated that the $\mathrm{EP}_{2}$ receptor predominates in the human ciliary muscle, as well as a small quantity of the DP receptor. At present it is unknown which prostanoid receptor, $\mathrm{EP}_{2}$ or DP, plays a more important role in reduction of intraocular pressure. The receptor types in the human ciliary muscle were the same as those found in the cat's ciliary muscle, while different from those in the rabbit's muscle as mentioned above. This means that care must be taken to apply results obtained in animal experiments to humans.

Development of conjunctival and intraocular inflammation is the major adverse effect of prostaglandins used topically as ocular hypotensive drugs. ${ }^{1-11}$ In rabbits, the $\mathrm{EP}_{2}$ prostanoid receptor subtype was involved in prostanoid induced breakdown of the blood aqueous barrier, ${ }^{28}$ in contrast with the $\mathrm{EP}_{3}$ receptor subtype related to ocular hypotension. ${ }^{26} \mathrm{It}$ is still unknown which subtype of the prostanoid receptor mediates development of intraocular inflammation in humans. However, the identification of the prostanoid receptor types located on the human ciliary muscle may help to develop pressure-reducing drugs which do not cause such inflammation.

This work was supported by an MRC fellowship to T Matsuo and by grants from Allergan, Inc, Irvine, CA, USA. The authors wish to thank Schering AG, Berlin, Germany for supplying sulprostone.

1 Giuffre G. The effects of prostaglandin F2alpha in the human eye. Graefes Arch.Clin Exp Ophthalmol 1985; 222: 139-41.

2 Lee PY, Shao H, Xu L, Qu CK. The effect of prostaglandin F2alpha on intracular pressure in normotensive human subjects. Invest Ophthalmol Vis Sci 1988; 29: 1474-7.

3 Villumsen J, Alm A. Prostaglandin $\mathrm{F}_{2 a}$ isopropylester eye drops: effects in normal human eyes. Br f Ophthalmol 1989; 73: 419-26. SM, et al. Maintained reduction of intraocular pressure by SM, et al. Maintained reduction of intraocular pressure by
prostaglandin F2alpha-1-isopropyl ester applied in multiple prostaglandin F2alpha-1-isopropyl ester applied in multiple mology 1989; 96: 1329-37.

mology
5 Villumsen J, Alm A, Soederstroem M. Prostaglandin $F_{24}$-isopropylester eye drops: effect on intraocular pressure in open-angle lester eye drops: effect on intraocular press
glaucoma. Br f Ophthalmol 1989; 73: 975-9.

6 Stern FA, Bito LZ. Comparison of the hypotensive and other ocula effects of prostaglandin E2 and F2alpha on cat and rhesus monkey eyes. Invest Ophthalmol Vis Sci 1982; 22: 588-98.

7 Bito LZ, Draga A, Blanco J, Camras CB. Long-term maintenance of reduced intraocular pressure by daily or twice daily topical of reduced intraocular pressure by daily or twice daily topical Ophthalmol Vis Sci 1983; 24: 312-9.

8 Bito LZ, Srinivasan BD, Baroody RA, Schubert H. Noninvasive observations on eyes of cats after long-term maintenance of reduced intraocular pressure by topical application of prostareduced intraocular pressure by topical application of
glandin E2. Invest Ophthalmol Vis Sci 1983; 24: 376-80.

9 Bito LZ. Comparison of the ocular hypotensive efficacy of eicosanoids and related compounds. Exp Eye Res 1984; 38: 181-94.

10 Goh Y, Nakajima M, Azuma I, Hayaishi O, Prostaglandin $D_{2}$ reduces intraocular pressure. Brf Ophthalmol 1988; 72: 461-4.

11 Woodward DF, Hawley SB, Williams LS, Ralston TR, Protzman CE, Spada CS, et al. Studies on the ocular pharmacology of

2 Gabelt BT, Kaufman PL. Prostaglandin F2alpha increases uveslceral outflow in the cynomolgus monkey. Exp Eye Res 1989; 49. siceral ou

13 Nilsson SFE, Samuelsson M, Bill A, Stjernschantz J. Increased uveoscleral outflow as a possible mechanism of ocular hypotension caused by prostaglandin F2alpha-1-isopropylester in the sion caused by prostaglandin F2alpha-1-isopropyl
cynomolgus monkey. Exp Eye Res 1989; 48: 707-16.

14 Crawford K, Kaufman PL. Pilocarpine antagonizes prostaglandin F2alpha-induced ocular hypotension in monkeys. Evidence fo enhancement of uveoscleral outflow by prostaglandin F2alpha. enhancement of uveoscleral outtlow

15 Matsuo T, Cynader MS. Localisation of prostaglandin $F_{2 u}$ and $E_{2}$ binding sites in the human eye. Brf Ophthalmol 1992; 76: 210-3.

16 Kennedy I, Coleman RA, Humphrey PPA, Levy GP, Lumley P Studies on the characterization of prostanoid receptors: a proStudies on the characterization of prostanoid recep.
posed classification. Prostaglandins 1982; 24: 667-89.

17 Coleman RA, Humphrey PPA, Kennedy I, Lumley P. Prostanoid receptors. The development of a working classification. Trends Pharmacol Sci 1984; 5: 303-6.

18 Dong YJ, Jones RL, Wilson NH. Prostaglandin E receptor subtypes in smooth muscle: agonist activities of stable prosta cyclin analogues. Br f P harmacol 1986; 87: 97-107.

19 Eglen RM, Whiting RL. Characterization of the prostanoid receptor profile of enprostil and isomers in smooth muscle and platelets tor profile of enprostil and isomers in smooth

20 Hirata $M$, Hayashi Y, Ushikubi F, Yokota Y, Kageyama $R$ Nakanishi S, et al. Cloning and expression of cDNA for a human thromboxane A2 receptor. Nature 1991; 349: 617-20.

21 Bhattacheriee P, Csukas S, Paterson CA. Prostaglandin E2 binding sites in bovine iris-ciliary body. Invest Ophthalmol Vis Sci 1990 31: 1109-13.

22 Aula P, Kaila T, Huupponen R, Salminen L, Iisalo E. Prosta glandin F2alpha binding to bovine ocular and synthetic melanins in vitro. Pharmacol Toxicol 1989; 65: 100-3.

23 Eriksson LO, Larsson B, Andersson KE. Biochemical characterization and autoradiographic localization of [3H]PGE2 binding sites tion and autoradiographic localization of [3H]PGE2
in rat kidney. Acta Physiol Scand 1990; 139: 405-15.

24 Shimizu T, Yamashita A, Hayaishi O. Specific binding of prostaglandin D2 to rat brain synaptic membrane. Occurrence, properglandin D2 to rat brain synaptic membrane. Occurrence,
ties, and distribution. $\mathcal{B ~ B i o l ~ C h e m ~ 1 9 8 2 ; ~ 2 5 7 : ~ 1 3 5 7 0 - 5 . ~}$

25 Woodward DF, Burke JA, Williams LS, Palmer BP, Wheeler LA, Woldemussie E, et al. Prostaglandin F2alpha effects on intraWoldemussie E, et al. Prostaglandin F2alpha effects on intra-
ocular pressure negatively correlate with FP-receptor stimula-

26 Waterbury LD, Eglen RM, Faurot GF, Cooper GF. EP3, but no EP2, FP, or TP prostanoid-receptor stimulation may reduce intraocular pressure. Invest Ophthalmol Vis Sci 1990; 31: 2560-7.

27 Chen J, Protzman CE, Woodward DF. Comparison of the pharmacology of prostanoid induced ciliary muscle relaxation and ocular to Invest Ophthalmol Vis Sci. Philadelphia: Lippincott, 1991: 870.

28 Protzman CE, Woodward DF. Prostanoid-induced blood-aqueous barrier breakdown in rabbits :nvolves the EP2 receptor subtype. Invest Ophthalmol Vis Sci 1990; 31: 2463-6. 